\title{
The Baltic States, Arms Brokers and Diversions of Arms
}

The illicit trade in arms, strategic and dual-use goods has attracted considerable international attention since the end of the Cold War. A particular interest has developed with regard to preventing the diversion of weapons from the licit market into the "black market'. This paper focuses explicitly upon the actors suspected of facilitating these diversions - arms brokers. After briefly considering the role played by 'middlemen' in the competitive licit arms market, the darker side of arms brokering will be explored.

Two cases involving Baltic States citizens will then be discussed, which illustrate how arms brokers operate from a variety of locations, use corrupt state officials, front companies, flags of convenience and circuitous routes with weak customs and border controls to supply 'undesirable end-users'. The potential of transport services in the Baltic States for brokering-related services will also be highlighted.

The Baltic States are among the few states which currently have legislation for defining, controlling and monitoring brokering activities. Yet, national controls are insufficient for preventing diversions, which require international co-operation. This paper considers the challenges posed for the Baltic States in this regard, and also the challenges that the Baltic States are posing for traditional thinking about international non-proliferation regimes. The paper concludes by asking: what role for the Baltic States in combating diversions from the licit to illicit arms markets and controlling brokers?

\section{Introduction}

Since the end of the Cold War, a number of factors have had an impact upon our thinking about the arms trade in general, and the illicit arms trade in particular. For example, there have been a number of general developments, such as the considerable changes in the significance and functions of borders, the disintegration and integration of states, the blurring of the categories of conflict and crime and a significant increase in international trade. But there have also been a number of important developments in the positions of researchers, NGOs and governments on the problems of the black market in arms, military equipment, strategic and dual-use goods and other instruments employed for killing and the abuse of human rights. In particular, it has been agreed that a priority for dealing with the black market should be to prevent the diversion of arms from the licit international arms market to the black market. This has, in turn, led to an increased level of attention being directed towards

* Dr. Paul Holton is a Research Fellow, Centre for Border Studies, University of Glamorgan. Address: Pontypridd, Wales, CF371DL, UK. Tel. +44 1443654174, e-mail - pholtom@glam.ac.uk 
the activities of individuals and enterprises which have for many years been operating in the grey areas and exploiting the loopholes of the licit arms trade, and assisting with covert arms transfers from governments to insurgents and end-users deemed internationally 'undesirable'. These individuals and enterprises are often described as 'middlemen', 'intermediaries', 'mediators' and a host of other names. For the purpose of this paper, I will refer to them primarily as arms brokers, and their activities will be discussed in more detail in the next section.

This paper seeks to highlight some of the challenges posed by arms brokers for the Baltic States, and some of the responses which have been, and could be, taken by the governments and those involved in the export control systems of Estonia, Latvia and Lithuania to help prevent diversions of arms and materiel passing from the licit to the illicit market. The first section will explore the rationale for employing brokers in the licit arms market using arguments put forward by the Latvian Ministry of Defence, before considering some of the concerns that have been expressed with the way in which brokers have been able to operate within legal 'grey areas', facilitate diversions of arms to illicit end-users, prey upon states with weak export/import control systems and 'feed' (and feed off) corrupt state officials. Two classic cases of brokered diversions of arms involving Baltic States' citizens will then be used to illustrate some of the practices employed by brokers willing to sell to organised crime groups and UN-embargoed states, and the ways in which corrupt state officials are involved, weak control systems evaded, problems with the length of time that it takes to convict a corrupt broker and the importance of good international co-operation for information exchanges and co-ordinating investigations within and across borders. These cases, to some extent, influenced the fact that the Baltic States have enacted legislation to control some brokering activities before 'older' EU Member States. In the final section of this paper, Baltic States' brokering controls will be discussed, noting the importance of international cooperation for successful implementation of national legislation in this sphere. Attention will also be drawn to a number of challenges and concerns with the implementation of brokering controls in general and in the Baltic States in particular.

\section{Arms Brokers and Methods for Diverting Arms}

Arms brokers can be defined as middlemen who organise arms transfers between two or more parties, often bringing together buyers, sellers, transporters, financiers and insurers to make a deal. They generally do so for financial gain, although political or religious motivation may also play a part in some deals. They often do not reside in the country from which the weapons originate, nor do they live in the countries through which the weapons pass or for which they are destined. As a result, such 'third party' arms brokering is notoriously difficult to trace, monitor and control. Arms brokers work very closely with transport or shipping agents. These agents contract transport facilities, carriers and crews in order to move arms cargoes by sea, air, rail or road ${ }^{1}$.

${ }^{1}$ BASIC, International Alert \& Saferworld, "Controlling arms brokering and transport agents: Time for international action", Briefing 8: Biting the Bullet, 2001, http://www.international-alert.org/pdf/ pubsec/btb_brf8.pdf, 26052004. 
According to Kathis Austin, director of the Arms and Conflict Program for the Fund for Peace, many governments and reputable arms manufacturing companies around the world rely on arms brokers for marketing their weapons and helping to arrange and facilitate sales ${ }^{2}$. In an increasingly competitive global arms market, they appear to have found a profitable niche. The Latvian daily newspaper Diena published a number of articles in 2004 on the role of brokers in assisting with supplying arms to the Latvian military, in which it was claimed that they provide a valuable service and can offer better value for money than buying direct from manufacturers ${ }^{3}$. These articles stated that in 2002 and 2003 the Latvian Ministry of Defence bought arms from nine Latvian companies, which did not manufacture armaments, to the value of 1.14 million Lati $(\cdot 1.73 \mathrm{~m} / \mathrm{US} \$ 2 \mathrm{~m})$ from a total of 1.3 million Lati $(\cdot 2 \mathrm{~m} /$ US $\$ 2.4 \mathrm{~m}$ ) spent on arms purchases in this period, with the remainder spent on purchases direct from foreign manufacturers.

The Diena articles question this reliance on Latvian intermediaries on a number of counts. Firstly, the claim that intermediaries are cheaper than buying direct from the manufacturer is questioned in one article by a Latvian corruption investigator, although it is claimed that intermediaries are only really used for small-scale orders (e.g. grenades, cartridges), with larger orders for weapons systems being conducted at the state-to-state level ${ }^{4}$. Secondly, an article written in February 2004 noted that tenders were only publicly announced in the Latvian government's newspaper, Latvijas Vestnesis, and on the home pages of the Ministry of Defence and Purchasing Supervisory Office (IUB), suggesting that this is why most firms competing for tenders were small Latvian intermediary firms. Since August 2004 the IUB no longer publishes announcements of military purchases on its website, and the Latvian Ministry of Defence no longer has to call for tenders or announce who will be supplying them. Opaqueness in military procurement has also been noted as a source of concern, due to possibilities for corruption, by analysts in Lithuania too ${ }^{5}$. Nevertheless, perhaps the most interesting line of questioning in Diena's articles stems from the fact that the Estonian and Lithuanian military buy directly from manufacturers or through state-to-state agreements on military co-operation. Neither state uses local or foreign intermediaries. If it is indeed cheaper to purchase arms in this manner, is it not surprising that Latvia's neighbours do not use local intermediaries? Why are their contacts with foreign suppliers better? But perhaps most importantly, an issue which was not explicitly raised in the Diena article is, why are the activities of, and rationale for, arms brokers and intermediaries meeting with increased suspicion and questioning?

\footnotetext{
${ }^{2}$ Austin K., "Illicit Arms Brokers: Aiding and Abetting Atrocities", The Brown Journal of World Affairs, 9 (1), 2002, p. 205.

${ }^{3}$ For example see: Krastinš J. \& Petersons K., "Ieroči armijai no Jelgavas un Rīgas", Diena web-site, 2402 2004, http://www.diena.lv, 1301 2005; Krastinš J., "Ieroču iepirkumi ar klusinātāju”, Diena web-site, 0909 2004, http://www.diena.lv, 13012005.

4 “Valdība sāk ieroču iegādi”, Diena web-site, 1006 2004, http://www.diena.lv, 13012005.

${ }^{5}$ Gricius A. \& Paulaskas K., "Democratic Control over the Armed Forces in Lithuania", Lithuanian Strategic Review 2002, Vilnius, 2003, p. 247; "Lithuanian Defence Spending is not fully transparent”, BBC Monitoring Report, 21102004 taken from Kauno Diena, 2010 2004, pp. 1 \&9.
} 
The answer to this last question is simple enough. A number of unscrupulous arms brokers are suspected of supplying arms to states subject to UN, OSCE and EU embargoes, terrorists and insurgents, organised crime groups and other 'undesirable' end-users and agents suspected of using weapons, military equipment, torture implements and dangerous materials for undesirable end-uses. Names such as Viktor Bout, Wilhelm Ehlers, and Sarkis Soghanalian have given arms brokers the unattractive soubriquet 'merchants of death', due to their "key responsibility in exacerbating violent conflict, promoting terrorism, advancing crime and breaking UN arms embargoes", according to Austin ${ }^{6}$. Although there are currently no legally binding international regulations and treaties on arms transfers, and hence no strict definitions in international law on what constitutes a licit or illicit arms sale or transfer, national export control legislation, UN, EU and OSCE sponsored arms embargoes and various international regimes on non-proliferation do allow us to distinguish, to some extent, between illicit and licit arms transfers and markets ${ }^{7}$. Arms brokers are thought to play a key role in moving shipments of arms which appear to conform to the laws and control systems of the exporting and importing states, into the hands of individuals, groups, movements and armies for whom the arms were not intended, and who are generally not permitted to purchase arms on the international licit arms market. Or in other cases, perhaps weapons and/or materiel which are not permitted for sale on the international arms market are discovered being traded by brokers. In other words, arms brokers are believed to not only play an important role in the licit arms market, but are also thought to play a crucial role in transferring arms from the licit to the illicit arms market and are also suspected of aiding governments with their covert or 'grey' arms transfers 8 .

The problem for those responsible for enforcing export control regimes and ensuring that arms shipments are received by the certified end-user is that arms brokers can be highly skilled at making it difficult to stop a diversion or even spot at which point on its journey the arms were diverted to an 'undesirable'/undesignated end-user. As two distinguished experts on arms brokering, Brian Wood and John Peleman, have discovered, "shipping agents and arms brokers go to considerable lengths to establish intricate international webs involving multiple subcontractors, front companies and circuitous transport routes". Research into arms brokering suggests that shipping agents, freight forwarders, financiers, insurers, and even government officials wittingly and unwittingly help to provide a mountain of paperwork to help conceal diversions. Due to the fact that lengthy and circuitous routes across numerous state borders have been used to assist with diversions, it is even possible that a combination of the following methods have been used in a single diverted transfer. A shipment may:

\footnotetext{
${ }^{6}$ Austin K., (note 2), p. 204.

${ }^{7}$ Gillard E-C., "What's Legal? What's Illegal?", in Lumpe L., ed., Running Guns: The Global Black Market in Small Arms, London: Zed Books, 2000, pp. 27-52.

${ }^{8}$ Marsh N., "Two Sides of the Same Coin? The Legal and Illegal Trade in Small Arms", The Brown Journal of World Affairs, 9 (1), 2002, pp. 221-3; Mathiak L. \& Lumpe L., "Government GunRunning to Guerillas", in Lumpe L., ed., Running Guns: The Global Black Market in Small Arms, London: Zed Books, 2000, pp. 55-80.

${ }^{9}$ Wood B. \& Peleman J., "Making the Deal and Moving the Goods: The Role of Brokers and Shippers", in Lumpe L, ed., Running Guns: The Global Black Market in Small Arms, London: Zed Books, 2000, p. 130.
} 
- at some stage have been smuggled across a border by not declaring the cargo to customs officials, or alternatively customs and/or border guards may have been bribed to turn a blind eye to the cargo's contents;

- have been mislabelled, with accompanying documentation declaring that the shipment contains farming machinery or foodstuffs, or documents may have been forged which announce that the shipment contains arms bound for country ' $x$ ', although it will eventually end up in country ' $y$ '.

Or, using some of the more dubious characters from their extensive network of state officials, arms brokers may have been able to 'persuade' a corrupt state official or two to supply documents that are not so much forged as bearing 'untruths'. An order, international import certificate, delivery verification certificate or 'receipt' for the shipment may have been issued by a member of country ' $x$ 's government or civil service, although the shipment may never even travel through country ' $x$ ' on its way to country ' $y$ '.

Such diversions have begun to garner an increased level of attention at the global level in recent years, as evidenced by the preparations for and proposals stemming from the 2001 'UN Conference on the Illicit Trade in Small Arms and Light Weapons in all its Aspects'. On a regional level, the EU has promoted various Joint Actions and continually develops its Code of Conduct on Arms Exports ${ }^{10}$. Since the mid-1990s, many states have been actively amending national legislation to increase the stringency on export and import controls for arms transfers. More requirements need to be satisfied before national authorities issue licences and permits for transfers, more detailed pre- and post- shipment checks and documentation now have to be provided, and, in some states, brokers need to be registered and in possession of a licence for each transfer in which they have played a role. Of course, this has not stopped diversions from taking place, but global, regional and national responses are becoming more co-ordinated and loopholes in legislation and control procedures are being closed.

The need for closing loopholes and ensuring clarity in national legislation and global and regional embargoes to effectively deter or help prosecute brokers involved in diversions of military equipment can be demonstrated with reference to Yuri Borisov and his Kaunas-based firm Avia Baltika, which specialises in selling and servicing helicopters. Lithuanian authorities have launched a number of investigations into this company's activities, for example deals with Sudan and Bangladesh, yet no convictions for diverting or smuggling military equipment to these states have followed. Borisov claims that these investigations were politically motivated, and has called for one of his main rivals, Helisota, to be investigated for corruption instead, alleging that it was awarded a contract to supply the Lithuanian military thanks to corrupt practices ${ }^{11}$. While some Lithuanian analysts may concur with the need for greater transparency in Lithuania's military purchases ${ }^{12}$, there is little doubt that

\footnotetext{
${ }^{10}$ For example, in the late 1990s the EU launched a Programme on Preventing and Combating the Illicit Trafficking of Conventional Arms (June 1997), a Code of Conduct on Arms Exports (June 1998) and a Joint Action on the EU's Contribution to Combating the Destabilising Accumulation and Spread of SALW (December 1998), and Plan of Action to Prevent, Combat and Eradicate the Illicit Trade in Small Arms and Light Weapons in all its Aspects (2000).

11 "Laisvas Laikrastis interview with Yuri Borisov", Laisvas Laikrastis, 0502 2004, http://www.laisvaslaikrastis.lt/EN, 13012005.

${ }^{12}$ Gricius A. \& Paulaskas K., (note 5), p. 247; "Lithuanian Defence Spending is not fully transparent" (note 5).
} 
many political analysts, commentators and elites would readily accept the unsavoury description of Borisov presented by the former head of the Lithuanian Security Services, Mecys Laurinkus, in a report to the Seimas at the end of October $2003^{13}$.

Despite allegations that Borisov has used, or intended to use, state officials in Lithuania to wittingly or unwittingly assist in the smuggling of military equipment to states under international embargoes such as Iraq, Libya and Sudan, he has not yet been convicted of arms smuggling. He has admitted to facilitating the supply of Mi-8T helicopters to Sudan in 2001, but in March 2003 an Interim Committee of the Lithuanian Parliament decreed that this act had not violated the laws of Lithuania in force at that time $^{14}$. The Ministry of Foreign Affairs did not approve Avia Baltika's application for a licence to export a Mi-8T helicopter to Sudan, and the Interim Committee stated that such an export ran counter to the principles of an EU embargo and sanctions, but it was not illegal in Lithuania in $2001^{15}$. Borisov has not yet been found guilty of transgressing any Lithuanian laws, despite the fact that he helped to send dual-use helicopters to Sudan, which may have been used in human rights abuses in the area. The fact that an arms dealer was being considered for a role in advising the Lithuanian president on security affairs is worrying, but again not necessarily illegal. It is for such reasons that the two cases described below should still be regarded as important, although the diversions discussed took place in the mid-1990s. They remain significant because there are still very few detailed accounts of the role played by brokers in diverting military equipment and arms to illicit end-users, and even fewer cases that have been taken to court.

\section{Brokering Balts and Diversion Concerns}

In this section, I will present two accounts in which citizens of the Baltic States have been found to be involved in brokering and attempting to divert seemingly legitimate arms transfers to end-users subject to UN embargoes and organised crime groups. These two accounts will be followed by more general concerns on brokering and diversions through the Baltic States.

\subsection{Lithuanian Brokers and Nukes for Columbia}

The first case to be discussed has been considered at length in other publications on arms brokering ${ }^{16}$, yet serves as a useful illustration of the potential danger posed by brokers. In 1995, two Lithuanian citizens, acting as brokers for the Bulgarian arms firm Armimex, were caught in a US sting operation after having successful-

\footnotetext{
${ }^{13}$ This supposedly secret memo from the Lithuanian Security Service to a parliamentary commission was evidently leaked, as within days extracts featured in the Lithuanian daily newspapers Respublika and Lietuvos Rytas.

14 "AviaBaltika accounts frozen by prosecutors", The Baltic Times, 11-17 12 2003, www.baltictimes.com, 13012005.

${ }^{15}$ Amnesty International, Arming the perpetrators of grave abuses in Darfur, AI Index: AFR 54/139/ 2004, 1611 2004, http://web.amnesty.org/library/Index/ENGAFR541392004, 13012005.

${ }^{16}$ See for example: Wood B. \& Peleman J., "Chapter 8: The USA: Getting Around the Toughest Law", The Arms Fixers: Controlling the Brokers and Shipping Agents, 1999, http://www.nisat.org/ default.asp?page=publications/pub_videos.htm, 26052004 .
} 
ly demonstrated their abilities at diverting weapons. Aleksandr Darichev (a.k.a. Daricev) and Aleksandr Pogrebzskii (a.k.a. Pogrebovksy; Pogrebeshki) believed that they were supplying weapons to a Columbian drugs cartel, but in fact they were supplying US customs agents. The publicly available details of the sting clearly demonstrate the way in which arms brokers operate from a variety of locations, use corrupt officials, front companies, flags of convenience and circuitous routes with weak customs and border controls to supply 'undesirable end-users'.

According to Wood and Peleman, Darichev and Pogrebzskii managed to acquire an end-user certificate from the Lithuanian Ministry of Defence, declaring that it was the purchaser of a missile system to be supplied by the Bulgarian firm Armimex. It was claimed that a false letter of receipt would be issued by the Lithuanian Ministry of Defence, even though the system was aboard a Cypriot-owned ship, which set sail from Lithuania, for Puerto Rico. On the way to Puerto Rico, the ship collected the weapons system from Bulgaria, where it was concealed amongst crates of machinery authorised for export to Puerto Rico. Although Darichev and Pogrebzskii were convicted of smuggling, money laundering and conspiracy, they were only sentenced to four years imprisonment ${ }^{17}$. Their activities, however, no doubt helped to demonstrate the need for controls on arms brokers, and in 1996 the US Congress passed an amendment to the US Arms Export Control Act, requiring all US nationals and foreign nationals residing or conducting business in the US of registering and obtaining licences for arms brokering.

\subsection{Breaking a Baltic Brokering Ring}

The second case to be recounted here focuses upon the role played by a former Latvian Colonel, suspected of diverting arms to UN-embargoed states and organised crime groups. I have discussed the case at greater length elsewhere, and with a greater emphasis upon the role of the Polish companies involved than I intend to here ${ }^{18}$. The tale begins in the Spring of 1992, when the re-established Latvian national army received a Polish 'donation' of surplus military materials. The transfer was not particularly lucrative, but the contacts established paved the way for a number of successful diversions of arms into the hands of 'undesirable' end-users.

The first known instance of diversion would appear to be a classic example of a corrupt official producing false declarations for order of arms. Janis is alleged to have sent an order for US\$2 million worth of arms and munitions to the Polish enterprise Cenrex, for which permission to export to Latvia from Poland was duly granted. In June 1992, the ship carrying US\$2 million worth of arms and munitions arrived at the Latvian port of Liepaja, but only US\$50,000 worth of AK-47 rifles and munitions were unloaded and taken to Latvian army depots, in accordance with the documents submitted by Colonel Janis to the relevant authorities in Latvia. The

\footnotetext{
${ }^{17}$ A full transcript of their indictment can be found on the PBS web-site: http://www.pbs.org/wgbh/ pages/frontline/shows/russia/scenario/indictment.html, 26052002.

${ }^{18}$ For a more detailed account see: Holtom P., Arms Transit in the Baltic Region, London: Saferworld, 2003, pp. 64-8.
} 
remainder of the ship's arms and munitions were subsequently transferred to a ship off the coast of Somalia, a state which was subject to a UN Security Council arms embargo at the time ${ }^{19}$. The method used for diverting the arms to Somalia is known as 'short-ordering'. This is when the order made by the importer is for more arms than they are registered as receiving. Therefore, there can be a considerable difference between the volume that the importer receives, and the volume that the authorities responsible for controlling imports believe have been received.

In September 1992, Colonel Janis again helped the director of Cenrex to divert arms to another state subject to a UN Security Council arms embargo - Croatia. A Latvian order for US $\$ 1.3$ million worth of arms was placed, and permission was granted for export from Poland. The ship transporting the arms left only US $\$ 50,000$ worth of its cargo in Latvia before docking in the Croatian port of Rijeka. In 1993, Janis was relieved of his post at the Latvian Ministry of Defence. No prosecution was brought against him at this time for 'short-ordering' or his role in diverting arms to states subject to UN Security Council arms embargoes. He was subsequently employed as a consultant for the Latvian-based arms company Arnex, which supplied arms to a number of Latvian governmental bodies.

It was not long before Janis was once again assisting his Polish contacts to divert arms via Latvia. This time, however, the ships carrying the arms did not even dock in Latvia. The arms were allegedly switched at sea with shipments of foodstuffs. Thus, ships carrying cargoes of pasta, flour and other foodstuffs arrived in Latvian ports, while ships carrying arms were unloaded at the Estonian fishing harbour of Miduranna. According to reports, four such diversions were made in the mid-1990s, with each shipment apparently consisting of US\$640,000 worth of TT pistols, assault rifles and ammunition. However, these shipments differed from Janis' earlier diversions, as the shipments were not bound for UN Security Council embargoed states, but Estonian arms dealers suspected of selling weapons to organised crime groups across Europe. And also in contrast to the earlier diversions, something went wrong with the diversion. This enabled law enforcement and security services in Estonia, Latvia and Poland to collect enough evidence to prosecute those involved in the diversions.

In 1996, the captain of one of the ships carrying arms refused to transfer his shipment at sea, and arrived in Riga with the arms still on board, much to Janis' chagrin. In an attempt to honour his 'contract', he sent the arms, mislabelled as foodstuffs, in a truck across the Latvian-Estonian border. The arms were discovered and the Estonian security services contacted their counterparts in Latvia and Poland and an international investigation began. In 1997 criminal proceedings were instigated against representatives of Arnex in relation to supplying arms to UN-embargoed Somalia and Croatia, and the diversions to Estonian arms dealers were also investigated $^{20}$. In May 2000, a criminal case against three Latvian citizens was sent to the Prosecutor General's Office. The case against Janis was dropped because of "time limitations", while the two other defendants were found guilty of arms trafficking in

\footnotetext{
${ }^{19}$ This case was cited in the 'Report of the team of experts appointed pursuant to Security Council resolution (2002), paragraph 1, concerning Somalia'.

20 "Latvian firm did break arms embargo on Somalia as UN claims", Neatkariga Rita Avize, 19 July 2002, http://www.nisat.org/default.asp?page=/search.asp, 26052004.
} 
2001. In these two cases, we are not only given information on the methods used for diversion, but also the apparent difficulty and controversy that ensues after arms brokers with connections in state institutions are caught diverting arms. Almost a decade passed between the initial diversions (that are known of) and a partially successful prosecution.

These two cases illustrate why brokering activities and diversions are a source for concern, and one would be complacent if they believed that such practices should be consigned to a box marked 'early transition experiences'. There remain concerns with the administrative capacity of the Baltic States to guard against diversions taking place in and around their states, corrupt practices, grey areas in legislation and the political sensitivity of investigating and prosecuting individuals or companies for brokering or smuggling if they have ties to state officials.

In addition to these cases, Estonia, Latvia and Lithuania have also provided arms brokers and dealers with the means for diverting shipments by air and sea, and the ports and airports of the Baltic States remain a cause for concern with regard to their potential as points for diversion. A number of reports have recently highlighted that the volume of cargo turnover passing through the ports of Tallinn, Klaipeda, Riga, and Ventspils alone is considerable ${ }^{21}$, with recent expansions, developments and the growth of competition for container shipments worrying because of their suspected use for arms trafficking ${ }^{22}$. The need for enhancing controls to prevent diversions of transfers of arms and other sensitive goods when passing through key transit and trans-shipment hubs is beginning to attract more international attention ${ }^{23}$, with measures such as the US-funded installation of a system for detecting WMD materials and data at Vilnius international airport suggesting concerns with the use of the Baltic States for diversions. The fact that in 2003 the route of a Helisota serviced helicopter bound for UAE was changed by Lithuanian authorities so that it no longer passed through Sudan, suggests that attempts are being made to limit the possibilities for diversion $\mathrm{s}^{24}$. And the discovery of aircraft and air defence system components by Latvian customs officials at Riga airport in August 2003, which according to documentation contained construction and farm machinery parts, and was bound for Iran from Russia, could also be regarded as a coup in combating attempts at arms smuggling $^{25}$. But what measures and responses have been taken by the Estonian, Latvian and Lithuanian governments to control brokering and prevent diversions?

${ }^{21}$ See for example: Brodin A., ed., Russian Transit Trade in the Baltic Sea Region, Centre for European Research, Goteborg University, 2002; Laurila J., "Determinants of transit transports between the European Union and Russia", BOFIT Online, 1, 2002, p. 26, http://www.bof.fi/bofit/ eng/7online/abs/pdf/bon0102.pdf, 26052004.

${ }^{22}$ It is feared that containers provide a particularly useful means for transporting illicit shipments of arms, see: The Economist, 4 April 2002, http://www.economist.com/, 1005 2003; Holtom P,. (note 18), pp. 16-19.

${ }^{23}$ See for example, "Emerging Issue: Transit and Transshipment Controls", NIS Export Control Observer, 4, 04 2003, p. 18, http://cns.miis.edu/pubs/nisexcon/pdfs/ob_0304e.pdf, 26052004.

${ }^{24}$ Amnesty International, (note 15 ).

${ }^{25}$ Interfax News Agency, Latvia opens criminal case following seizure of arms bound for Iran,

29082003 . 


\section{Arms Controls, International Co-operation and Concerns}

While all three Baltic States have subjected certain shipments of arms, strategic and dual-use goods travelling in transit through their territories to controls since the early 1990s, their legislation on import, export and transit controls has been subject to numerous amendments and even new laws. The most recent Estonian, Latvian and Lithuanian laws on export, import and transit controls for arms and strategic and dual-use goods, and lists of arms, strategic goods and countries subject to controls, all explicitly refer to their compliance with EU Joint Actions, directives and the EU Code of Conduct on Arms Exports. In addition, Estonia, Latvia and Lithuania have publicly supported the OSCE's Document on SALW and signed the Firearms Protocol of the UN Convention against Transnational Organised Crime.

More significantly for this paper, all three states have defined brokering activities in their national legislation, and require nationals and residents involved in such activities to be licensed and subject to controls and monitoring. In 2004, they constituted 3 of the 25 states worldwide that had legislation controlling the activities of arms brokers, helping to boost the number of EU member states with such legislation from 8 to 16 after enlargement.

Although it has been stated that brokerage controls have been in place in Estonia since $2001^{26}$, the legislative base became far clearer with the enactment of the Strategic Goods Act of the Republic of Estonia (2003) ${ }^{27}$. Thus any Estonian citizen or resident involved in acquiring military goods, providing information, practical assistance or funds for a transaction between two third parties located outside Estonia must now hold a permit to engage in such activities, be placed on the national register of brokers and apply for a licence for each transaction in which they are involved. Therefore, Estonia has enacted a system for controlling brokering that is in line with many of the recommendations contained in the EU Council's 'Common Position on the Control of Arms Brokering' (23 June 2003) ${ }^{28}$.

Latvian authorities claim that they have had a system for controlling brokering activities in place since 1997, referring to the fact that since this date companies owned by Latvian citizens, or permanent residents of Latvia, must hold a Latvianissued transit license if they are involved in the transfer of strategic goods from one foreign country to another country via a third-country, even if the transit shipment did not enter or leave the territory of Latvia ${ }^{29}$. However, it had been unclear whether this would also apply to extra-territorial cases, as is the case in Belgian law, and as no case was brought against a Latvian individual or company on these grounds, the question remained purely theoretical. Latvia has, however, kept a database for a number of years on arms transactions carried out by Latvian enterprises, including

\footnotetext{
${ }^{26}$ Estonian Government Order No. 154 'On Confirming the List of Strategic Goods', 30042001. 27 'Strategic Goods Act of the Republic of Estonia', in force since 05022004

${ }^{28}$ EU Council 'Common Position on the Control of Arms Brokering' 2003/468/CFSP, 2306 2003.

${ }^{29}$ Latvian Cabinet of Ministers' Regulations 'On Control of Strategic Goods', 16121997.
} 
entities that could be defined as brokers. And, like its neighbours, Latvia has also recently enacted a number of laws with more detailed information on brokering requirements in line with the 'Common Position on Arms Brokering' prior to accession to the $\mathrm{EU}^{30}$.

In Lithuania, controls were also introduced on brokering activities to help prevent diversions before joining the EU in 2004. In recent years a number of pieces of legislation with reference to military equipment, weapons and ammunition have been enacted that broadly define brokering activities and call for permits and licences to be held and registers to be compiled ${ }^{31}$, therefore also putting a control system for brokering in place before 'older' EU Member States such as Greece, Luxembourg and the UK.

However, as with other EU efforts to prevent diversion from the licit to the illicit arms market and combat trafficking, the Common Position has already been criticised for its low minimum standards. Rather than calling for the adoption of best practice already on the statute books of EU Member States such as Belgium, Finland and Germany, states are invited to 'consider' or 'may' be required to introduce certain measures. Yet, despite concerns that the EU Council did not ascribe enough importance to increasing controls on brokering-related activities, extra-territorial controls and the continued lack of a 'standard model' position for licensing, monitoring and recording arms brokers and their transactions ${ }^{32}$, the Baltic States appear to have included some of the more stringent controls on brokering applied by other EU Member States in their legislation on export, import and transit controls.

Unfortunately, well-meant legislation does not implement and enforce itself. For example, in the five years following the arms brokering amendment to the US Arms Export Control Act, there had not been a single prosecution of an arms broker based on this amendment ${ }^{33}$, although some have argued that there is anecdotal evidence that it has served as a deterrent ${ }^{34}$. The US controls on arms brokering have not yet been tested. Fears have also been voiced by Polish experts on arms control that although legislators can justifiably feel proud of their legislation on controlling arms brokers and closing the loopholes that had previously made it difficult to launch a successful prosecution against those involved in diversions, Poland lacks the ability to enforce this legislation. Similar concerns have been voiced by Latvian officials regarding Latvia's ability to enforce its requirement for Latvian-owned enterprises and entities based overseas to hold licences and permits if involved in an arms trans-

\footnotetext{
30 'Law on Arms Circulation', in force since 0101 2003; 'Law on the Circulation of Strategic Goods', in force since 01052004.

31 'Law On Amending the Law on the Control of Import, Transit and Export of Strategic Goods and Technologies', approved 0502 2002; 'Law on the Control of Arms and Ammunition', in force since 01072003.

${ }^{32}$ For more detailed critiques of the EU's Common Position on the Control of Arms Brokering see: Amnesty International, Undermining Global Security. The European Union's Arms Exports, London: Amnesty International, May 2004; Anders H., Controlling Arms Brokering. Next Steps for EU Member States, Brussels: GRIP, January 2004, http:/www.grip.org, 2605 2004. Anders also offers a useful overview of brokering legislation in the pre-2004 enlargement EU.

${ }^{33}$ Austin K., (note 2), p. 207.

${ }^{34}$ Amnesty International, (note 32), p. 29.
} 
fer that does not pass through Latvia's borders. And this is without mentioning concerns about the abilities of all three states to prevent diversions taking place via their airports, ports or land border crossings. The assessments of the EU and Council of Europe's Group of States Against Corruption (GRECO) regarding the judiciary, law enforcement, border and customs services of Estonia, Latvia and Lithuania highlighted a number of general concerns with corruption, experience, and resources, which could have an impact upon the ability of these states to uncover attempted diversions and arms brokering activities.

Some of these general concerns and shortcomings in relation to arms controls and law enforcement, customs and border provisions are being actively addressed with international assistance from EU funds and bi-lateral and multi-lateral projects with EU Member States, the USA, Norway and other states. Estonia, Latvia and Lithuania have concluded a number of co-operation agreements for combating organised crime, and best practice training and equipment provisioning for customs, border and law enforcement with neighbours in the Baltic Sea and other EU Member States $^{35}$. However, it does not yet appear that assistance with implementing brokering controls has been offered. A number of NGO-sponsored reports are now actively highlighting the fact that not enough attention was given to the export control systems of those states acceding to the EU in 2004, and that more technical and financial assistance has to be rendered now ${ }^{36}$. The rationale is that an EU-wide control system is only as strong as its weakest link, and many advocates of stringent export and broker controls consider the new member states to be weak links due to concerns with their administrative capacity.

Of course, due to their very nature, the monitoring of brokering activities and preventing the diversion of arms and strategic goods to the international illicit arms trade require multi-lateral co-operation. International non-proliferation regimes such as the Australian Group (AG), the Missile Technology Control Regime (MTCR), the Nuclear Non-proliferation Treaty (NPT), the Nuclear Suppliers Group (NSG) and the Wassenaar Arrangment (WA) were established to more effectively counter proliferation by providing forums for information exchanges on materials, goods and dubious end-users. However, membership of such regimes has tended to be limited to states which house manufacturers and suppliers of certain goods and materials. And, therefore, the Baltic States did not appear to have sufficient grounds on which to join these regimes. Yet membership of these regimes continues to be stated as amongst the most important foreign and security priorities of Estonia, Latvia and Lithuania. Thus, the Baltic States are challenging the twentieth century non-proliferation regimes to reform to meet the challenges of the twenty-first century, and with some success. For example, Estonia and Lithuania were admitted to the Nuclear Suppliers Group in May 2004. Toomas Raba, an Estonian export control practitioner, has argued persuasively for small transit states such as Estonia to be admitted to international regimes, even if they are not manufacturers or suppliers of controlled goods and materials, because:

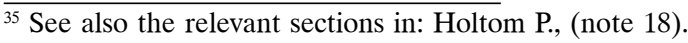

${ }^{36}$ Amnesty International, (note 32), p. 95.
} 
- transit states need to participate in information sharing processes if they are to successfully ensure that merchandise that may pose a danger to international security is not being diverted. In cases where so-called 'dual-use goods', for example goods which can be used in the manufacture of nuclear weapons but which can also be employed for other 'civilian' purposes, are being transferred across the Baltic States, or a Baltic broker is involved in a transfer of such materials, without access to information restricted to regime members, permission may be granted by Estonia, Latvia or Lithuania for the materials to be transported to an end-user who should not receive such materials;

- small states have limited human, financial and intelligence resources to monitor end-users and end-uses, and therefore co-operation with other countries is essential for pre-shipment controls and post-shipment monitoring ${ }^{37}$.

For Raba, although the Baltic States already co-operate and exchange information with regime members, for example through Baltic Sea and EU structures, this is not enough to ensure that Estonia, Latvia and Lithuania can effectively prevent dangerous goods and materials being delivered or diverted to undesirable end-users. Of course, Raba notes that regional co-operation forums such as ad-hoc Baltic/Nordic States information sharing and EU COARM meetings are essential for strengthening national and international controls as they provide an opportunity for establishing good personal relations, developing trust, goodwill and like-mindedness, all deemed essential 'cornerstones' for effective information sharing relating to pre- and post- shipment controls on end-users. Yet such geographically limited relationships are insufficient for preventing diversions, which are potentially global in scope.

However, regional arrangements for exchanging information in relation to arms controls do offer potential starting points for moving towards global controls on arms brokering activities. If the EU is successful in establishing an effective system for exchanging information on legislation, registered brokers, records of their transactions and denials, and willing to extend this arrangement to third states or groupings of states, a global information exchange network could be developed. The EU has already successfully exported its Code of Conduct to applicant states and beyond. Is it possible that a similar process could be promoted with regard to its Common Position on the Control of Arms Brokering, with the annual enhancements to the Code of Conduct also being issued with regard to brokering controls? And what role for the Baltic States?

\section{Conclusion}

There are a number of actions which the Baltic States could take individually or via multi-lateral mechanisms to assist with the prevention of diversions from the licit to the illicit arms market and undesirable end-users. The Baltic States should continue to challenge traditional non-proliferation regimes and models and support regional and global efforts to combat illicit arms trafficking and diversions. For example, the Baltic States "should actively support a process to develop a legally

${ }^{37}$ Raba T., "Enhancing export controls in transit states", The Monitor: International Perspectives in Nonproliferation, 8 (2), 2002, pp. 19-21. 
binding international arms trade treaty"38. A number of international NGOs are pushing for a global arms trade framework, which would require commitments to greater transparency and accountability, the licensing of overseas arms production, the registration and monitoring of arms brokers and brokering-related services, better stockpile management and destruction programmes, clearer and more stringent transit and trans-shipment controls, in addition to global controls not only for military equipment, but also for surveillance, torture and non-tangible transfers and improved mechanisms for monitoring end-use ${ }^{39}$.

Perhaps the easiest and most straightforward action that the Baltic States could undertake would be to provide other EU Member States with information on brokers registered in these states, and details of their transactions and most importantly denials. This would demonstrate that they are not weak links but actively participating in efforts to control the licit arms trade and prevent diversions. This could be further demonstrated by producing 'model' annual reports on import, export and transit shipments of arms, military equipment, and other strategic and dual-use goods, going beyond the minimum requirements stipulated by Criterion 8 of the EU's Code of Conduct on Arms Exports. At the same time, due to concerns with the potential for corruption in procurement practices of arms for the military and other governmental bodies, efforts should be undertaken to increase the quality of parliamentary scrutiny of exports, imports and transit shipments of arms. Assistance could be requested from other EU Member Parliaments, national and international NGOs if it is felt that parliamentarians are not currently equipped with sufficient knowledge to undertake such tasks. It would also appear that media outlets in the area are also beginning to take an interest in exports and imports of arms, and the threats posed by arms brokers with interests in unstable regions, hopefully also leading to better informed civil societies in this sphere.

The Baltic States could assist the international struggle with unscrupulous arms brokers by instigating a test case based on their newly improved national legislation. This may well be one of the most challenging suggestions contained in this conclusion, as it calls for far more than political rhetoric and legislating. Firstly, it requires the good fortune that helped Estonian, Latvian and Polish law enforcement agencies to unravel the arms trafficking network described above. And secondly, it will need a considerable amount of political will and bravery to bring to trial and hear the testimonies of individuals who could implicate a number of government officials in the Baltic States and other states.

${ }^{38}$ Amnesty International, (note 32), p. 98.

${ }^{39}$ Ibidem. 